Int. J. Plant Sci. 170(3):365-380. 2009.

(c) 2009 by The University of Chicago. All rights reserved.

1058-5893/2009/17003-0009\$15.00 DOI: $10.1086 / 596332$

\title{
PHYLOGENY, BIOGEOGRAPHY, AND CHARACTER EVOLUTION IN MEDITERRANEAN, ASIATIC, AND MACARONESIAN HELICHRYSUM (ASTERACEAE, GNAPHALIEAE) INFERRED FROM NUCLEAR PHYLOGENETIC ANALYSES
}

\author{
Mercè Galbany-Casals, ${ }^{1, *}$ Núria Garcia-Jacas, ${ }^{*}$ Llorenç Sáez, $†$ Carles Benedí,‡ and Alfonso Susanna* \\ *Institut Botànic de Barcelona (Consejo Superior de Investigaciones Científicas-Institut de Cultura de Barcelona), Passeig del Migdia s/n, Parc de \\ Montjuïc, 08038 Barcelona, Spain; †Unitat de Botànica, Departament de Biologia Animal, Biologia Vegetal i Ecologia, Facultat de Ciències, \\ Universitat Autònoma de Barcelona, 08193 Bellaterra, Spain; and ¥Departament de Productes Naturals, Biologia Vegetal i Edafologia, \\ Unitat de Botànica, Facultat de Farmàcia, Universitat de Barcelona, Avenida Joan XXIII s/n, 08028 Barcelona, Spain
}

\begin{abstract}
The genus Helichrysum has 500-600 species in Africa, Madagascar, the Mediterranean basin, Macaronesia, western and central Asia, and India. The aims of this study are to confirm the exclusion of Castroviejoa from Helichrysum, to elucidate the origin of the Macaronesian endemics, to confirm the monophyly of the Mediterranean-Asiatic group, and, within this group, to contrast molecular data with sectional classification and to provide insight into trends in character evolution and biogeography. To address these issues, ITS and ETS sequences were used in phylogenetic analyses. Results show that Castroviejoa is excluded from Helichrysum. The phylogeny obtained suggests a southern African origin for Helichrysum and several subsequent migrations throughout the African continent. The species from the Canary Islands do not form a monophyletic clade, suggesting that at least two independent colonization events occurred. Helichrysum makranicum, from Oman and southern Iran, is the closest relative of a clade consisting of two endemics of the Canary Islands, providing new evidence of the phytogeographical links between Macaronesia and eastern Africa-southern Arabia. Helichrysum gossypinum, the third endemic of the Canary Islands, is the sister species of a monophyletic Mediterranean and Asiatic group, with the four endemics of Madeira sister to all of them. Within the Mediterranean-Asiatic clade, sect. Stoechadina is monophyletic, but sect. Helichrysum and sect. Virginea are not. Once in the Mediterranean region, the genus is hypothesized to have diversified and expanded to the east up to western and central Asia and to have suffered a reduction in woodiness.
\end{abstract}

Keywords: Castroviejoa, Canary Islands, Madeira, ETS, ITS, hybridization.

Online enhancement: appendix table.

\section{Introduction}

The genus Helichrysum Mill. (Gnaphalieae) is distributed throughout the African continent, Madagascar, the Mediterranean basin, Macaronesia, western and central Asia, and India (Anderberg 1991) and comprises 500 (Hilliard 1983) to 600 (Anderberg 1991; Bayer et al. 2007) species, making it one of the largest genera in the Asteraceae. It includes a great diversity of life forms, from annual plants to trees, although most of the species are subshrubs or shrubs. The genus is characterized as having homogamous or heterogamous capitula, generally with hermaphrodite florets outnumbering female florets; phyllaries with a fenestrated stereome; a flat, generally smooth or toothed receptacle; cypselae glabrous or covered with duplex or twin hairs; and a pappus that is monomorphic and usually uniseriate, consists of several scabrid to plumose bristles, and is free at the base (Hilliard and Burtt 1981).

Helichrysum is a large and taxonomically difficult genus, and its circumscription has undergone notable changes, because the traditional concept of the genus included an assemblage

${ }^{1}$ Author for correspondence; e-mail: pallenis@yahoo.com.

Manuscript received July 2008; revised manuscript received September 2008. of numerous heterogeneous taxa. It has been repeatedly stated that Australian and New Zealand species traditionally known as Helichrysum certainly belong to other taxonomic groups, mainly to genera from either the subtribe Angianthinae or the subtribe Cassiniinae (Anderberg 1991; Bayer et al. 2002). These suggestions have since been supported by a molecular phylogenetic work based on ITS sequences (Galbany-Casals et al. 2004a).

A considerable number of changes, based on morphology, have been made concerning the generic delimitation of African Helichrysum species and several related genera. Many species have been placed in other genera (e.g., Syncarpha DC. [Anderberg 1991; Nordenstam 2003], Edmondia Cass., Dolichothrix Hilliard \& B. L. Burtt, Atrichantha Hilliard \& B. L. Burtt, and Plecostachys Hilliard \& B. L. Burtt [Hilliard and Burtt 1981]), while others have been transferred into Helichrysum from related genera (e.g., Leontonyx Cass. [Hilliard and Burtt 1981]). Finally, some genera closely related to Helichrysum, such as Achyrocline (Less.) DC. and Pseudognaphalium Kirp., cannot be segregated from Helichrysum by any qualitative morphological character, and some authors suggest that their circumscription should be revised (Hilliard and Burtt 1981; Anderberg 1991). Despite all these rearrangements of generic 
circumscription based on morphology, recent molecular phylogenetic works that included African Helichrysum species have confirmed that Helichrysum is still polyphyletic (Bayer et al. 2000; Galbany-Casals et al. 2004a). For example, H. dasyanthum (Willd.) Sweet, from southern Africa, is closely related to Anaxeton laeve (Harv.) Lundgren, from the Cassiniinae, rather than to other Helichrysum species.

Finally, still in relation to generic delimitation, in a phylogenetic work based on ITS sequences, $H$. frigidum (Labill.) Willd. and $H$. montelinasanum Schmid, two Mediterranean species, were excluded from the Helichrysum clade and placed with other genera coded as outgroup taxa (Galbany-Casals et al. $2004 a$ ). After a detailed study based on morphological traits, these two species were transferred to a new genus, Castroviejoa Galbany, L. Sáez \& Benedí (Galbany-Casals et al. 2004b, 2004c).

The only exhaustive treatment of Helichrysum is that of de Candolle (1838). However, de Candolle's classification is very incomplete (including 215 of the 500-600 species currently recognized) and does not always reflect natural phylogenetic relationships within species, which makes his classification unreliable. Main recent treatments are those of floristic works and therefore are partial. Hilliard (1983) classified the 245 southern African species into 30 informal groups based on differences in habit; receptacle, stereome, and pappus morphology; and ratio of pistillate and hermaphrodite florets, among other characters. Humbert (1962) also proposed 11 informal groups to classify the 115 species from Madagascar, mainly using differences in habit, leaf morphology, capitula shape and size, and receptacle morphology. Finally, Tadesse and Reilly (1995), in their treatment of the species from northeastern tropical Africa (Ethiopia, Sudan, and Somalia), did not propose any infrageneric classification for the 29 species included, nor did Beentje (2002) in his proposal for the 46 species from eastern tropical Africa (Tanzania, Uganda, and Kenya). This lack of a complete and satisfactory infrageneric classification for the African species reflects the taxonomic difficulty of the genus and the scarcity of morphological characters that could allow the establishment of infrageneric categories.

The genus Helichrysum also has some representatives in Macaronesia. Three species are endemic to the Canary Islands: H. gossypinum Webb, from Lanzarote, H. monogynum B. L. Burtt \& Sunding, also from Lanzarote, and H. alucense J. García-Casanova, S. Scholz \& E. Hernández, from La Gomera; and four species are endemic to Madeira: H. devium J. Y. Johnson, H. melaleucum Rchb. ex Holl, H. monizii Lowe, and H. obconicum DC. The geographic origins of the Macaronesian flora have been examined in both traditional and molecular studies. Using the former approach, Bramwell (1976) examined patterns of geographic distribution, endemism, chromosome data, and morphology and stated that part of the flora of the Canary Islands is relict in origin and derived from Mediterranean relatives present during the Tertiary, since a continuous flora was present in northern Africa and the Mediterranean region in the late Miocene (Axelrod 1975; Quézel 1978; Sunding 1979). Other data on distribution patterns of many genera indicate that most of the modern flora of the Canary Islands is of African origin and that the closest relatives of many taxa on these islands are in eastern Africa and southern Arabia. A general "track" unifying southern Africa, eastern Africa, and, through the Sahara, the Mediterranean region and Macaronesia has been proposed (Bramwell 1985). This general African migration track mostly agrees with African migration routes for the Pliocene and Pleistocene flora suggested by Quézel (1978).

Molecular studies hold that several elements of Macaronesian flora derive from a range of areas including Eurosiberia (e.g., Saxifraga: Vargas et al. 1999b), northwestern Africa (e.g., Lotus: Allan et al. 2004; Reseda: Martín-Bravo et al. 2007), eastern Africa (several examples, reviewed by Andrus et al. [2004]), southern Africa (e.g., Phyllis and Anthospermum: Bremer 1996; Andersson and Rova 1999), and the Mediterranean region (e.g., Argyranthemum, the Asteriscus alliance: Francisco-Ortega et al. 1997, 1999; Ixanthus: Thiv et al. 1999; Bencomia: Helfgott et al. 2000; Sideritis: Barber et al. 2002; Descurainia: Goodson et al. 2006). A number of these studies show monophyletic groups of Macaronesian taxa, which indicates a single origin and colonization of the islands followed by diversification within the islands, including interisland colonization (Francisco-Ortega et al. 1997, 1999, 2001; Helfgott et al. 2000; Barber et al. 2002; Allan et al. 2004). In contrast, other studies support the hypothesis of multiple colonization events of Macaronesia from continental sources (Hedera: Vargas et al. 1999a; Ilex: Cuénoud et al. 2000; Olea: Hess et al. 2000; Tolpis: Park et al. 2001; Lavatera: Fuertes-Aguilar et al. 2002; Teline: Percy and Cronk 2002). In a previous phylogenetic work, Helichrysum alucense, endemic to La Gomera and the only species from Macaronesia included in the analysis, was grouped with the African Helichrysum, which is more closely related to African representatives than to Mediterranean ones (Galbany-Casals et al. 2004a). The origin of the other Macaronesian species is still uncertain, as is the matter of whether all the Macaronesian species constitute a monophyletic group derived from a single colonization event, on the one hand, or from several events, on the other.

In the Mediterranean region and western and central Asia, 41 taxa of Helichrysum, including subspecies, are found, 19 of which were included in a previous phylogeny of the genus and that showed them to be a highly supported monophyletic group derived from African ancestors (Galbany-Casals et al. $2004 a$ ). The most recent treatments of this group recognize three sections that do not overlap and have no correspondence with the African informal groups: sect. Stoechadina (DC.) Gren. \& Godr., sect. Helichrysum, and sect. Virginea (DC.) Gren. \& Godr. (Clapham 1976; Galbany-Casals et al. 2006). Species of sect. Stoechadina generally have a western-central Mediterranean distribution and consist of shrubs or subshrubs (fig. 1A). They never have conspicuous overwintering buds, stolons, or rhizomes, and only $H$. crassifolium (L.) D. Don has basal leaf rosettes. Representatives of sect. Stoechadina were grouped in a moderately supported monophyletic clade in a previous study, but internal relationships within this group were unresolved (Galbany-Casals et al. 2004a). Species from sect. Helichrysum and sect. Virginea are suffruticose and generally have leaf rosettes that often bear conspicuous overwintering buds (fig. $1 B$ ). Some species have homogamous capitula and others heterogamous ones. The morphological differences between sect. Helichrysum and sect. Virginea are as follows (Clapham 1976): Species in sect. Helichrysum have capitula with yellow, rarely white, nonradiating phyllaries that nearly 


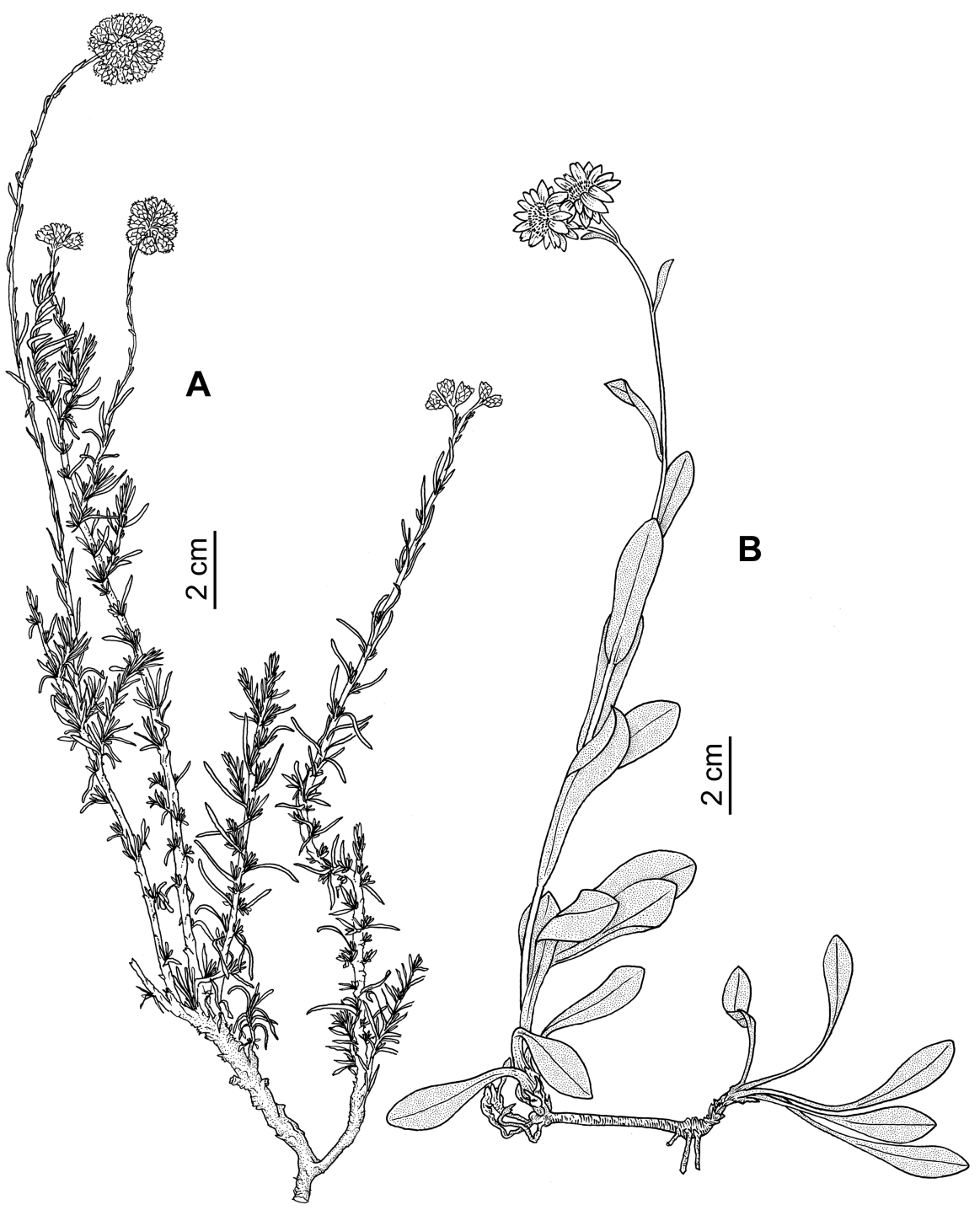

Fig. 1 Two types of habit in the Mediterranean and Asiatic Helichrysum: A, Shrubby plants, with vegetative stems well developed and without leaf rosettes; $B$, suffruticose plants, with leaf rosettes and often with overwintering buds conspicuously swollen.

equal the florets in length, and the innermost phyllaries are longer than the middle ones (fig. 2A). In contrast, species in sect. Virginea have capitula with white, radiating phyllaries that extend beyond the florets, and the middle phyllaries are longer than the innermost ones (fig. 2B). The species included in sect. Virginea are distributed in the central and eastern Mediterranean regions, whereas sect. Helichrysum includes taxa with eastern Mediterranean and western and central Asiatic distributions. In a previous ITS sequence-based study, sect. Virginea was not supported, because the two representatives of the section, H. sibthorpii Rouy and H. taenari Rothm., were not grouped in a monophyletic clade (Galbany-Casals et al. 2004a).

In this article, we add new material that contributes to a more complete sampling of the Mediterranean-Asiatic group, including all the Macaronesian endemic species, within a wider survey of the genus, including many species from tropical and southern Africa. Moreover, in view of the low resolution of the ITS within the Mediterranean-Asiatic group, we add a new marker, the ETS (external transcribed spacer), which has been used in the Asteraceae (e.g., Baldwin and Markos 1998; Clevinger and Panero 2000; Urbatsch et al. 2003; Suárez-Santiago et al. 2007) and the Gnaphalieae (Bayer et al. 2002).

Our aims are (1) to test the hypothesized monophyly of the Mediterranean-Asiatic Helichrysum, using a more complete sampling; (2) to contrast molecular data with the traditional sectional classification and morphology in this group; (3) to provide additional insight into character evolution in this group; (4) to examine the origin and affinities of Helichrysum species from the Canary Islands and Madeira and infer the colonization pattern of these islands; and (5) to provide additional support, based on broader taxonomic sampling, for the exclusion of Castroviejoa from Helichrysum. 


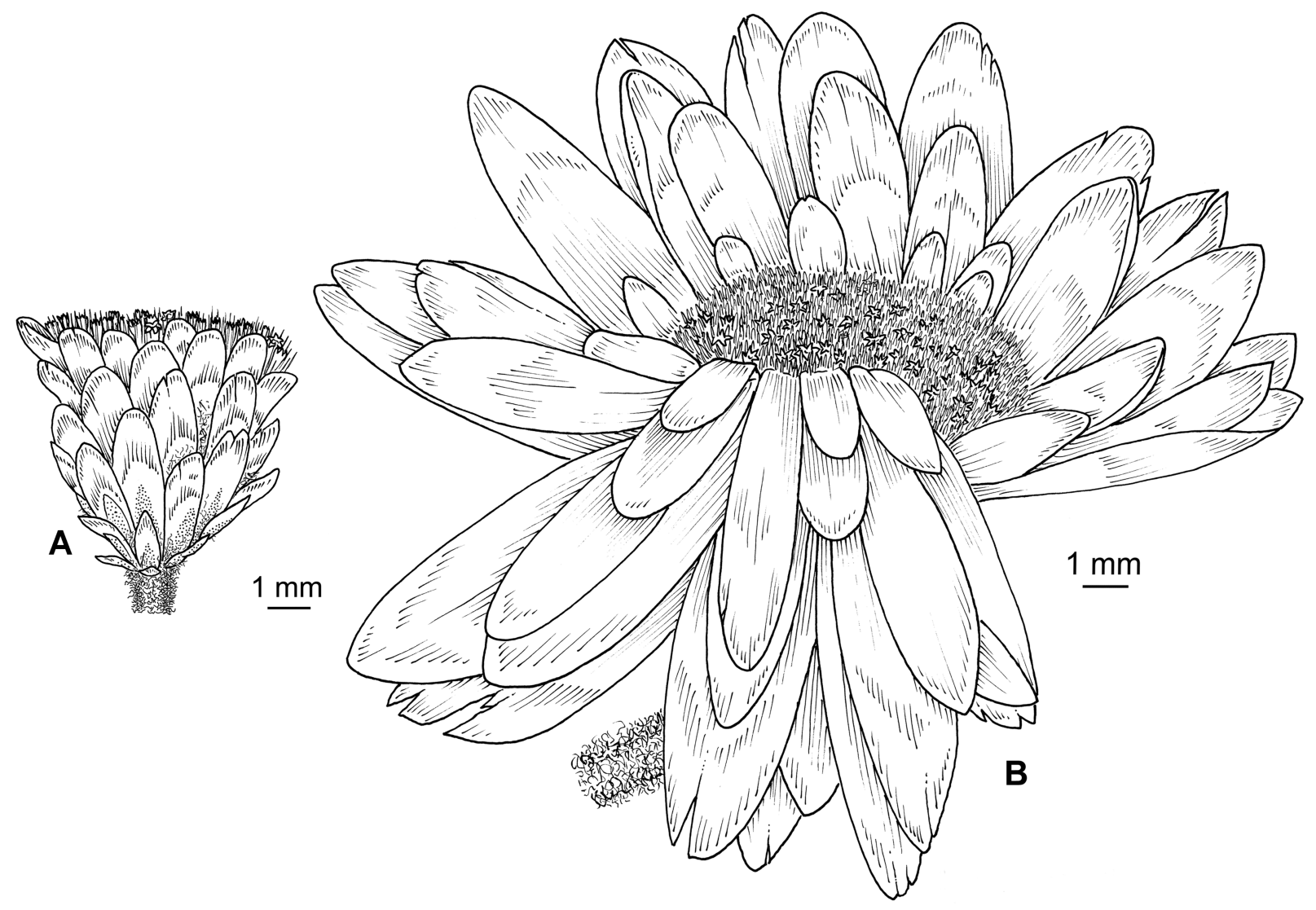

Fig. 2 Two types of capitula in the Mediterranean and Asiatic Helichrysum: A, Stoechadina and Helichrysum type, with nonradiating phyllaries that nearly equal the florets in length and innermost phyllaries that are longer than the middle ones; $B$, Virginea type, with radiating phyllaries that extend beyond the florets and middle phyllaries that are longer than the innermost ones.

\section{Material and Methods}

\section{Plants}

We have included 36 representatives of the 41 Mediterranean and Asiatic Helichrysum and 47 representatives of African Helichrysum. The African species were selected to widen the representation of the genus and comprise 15 species from tropical Africa and 32 from southern Africa, representing 28 of the 30 informal groups recognized by Hilliard (1983). In addition, H. makranicum (Rech. f. \& Esfand.) Rech. f., from Oman and southern Iran, and H. arwae J. R. I. Wood, from Yemen, have been included. Our sampling of the genus also comprises the three endemic species of the Canary Islands and the four endemic species of the Madeiran Archipelago. We have also included Anaxeton laeve, Syncarpha mucronata (P. J. Bergius) B. Nord., Helichrysum dasyanthum, and Plecostachys serpyllifolia (P. J. Bergius) Hilliard \& B. L. Burtt as outgroup taxa, according to previous sequence analyses (Bayer et al. 2000; Galbany-Casals et al. 2004a). Finally, Castroviejoa frigida (Labill.) Galbany, L. Sáez \& Benedí and C. montelinasana (Schmid) Galbany, L. Sáez \& Benedí have been included. In total, we have included in the analyses 96 ITS sequences, of which 58 are new, and 46 ETS sequences, all of which are new. Voucher data, the origin of the material, and GenBank sequence accession numbers are given in table A1 in the online edition of the International Journal of Plant Sciences.

\section{DNA Extraction, Amplification, and Sequencing}

Total genomic DNA was extracted with the CTAB method of Doyle and Doyle (1987), as modified by Cullings (1992), from silica-gel-dried leaves collected in the field, fresh plants cultivated at the Botanic Institute of Barcelona, or herbarium material. For difficult material, the commercial kits NucleoSpin Plant (Macherey-Nagel, Düren, Germany) and DNeasy Extraction Kit (Qiagen, Hilden, Germany) were used, following the manufacturers' instructions.

\section{Nuclear Ribosomal DNA (nrDNA) ITS Region Strategies}

The ITS DNA region was amplified using the 17SE forward and 26SE reverse primers (Sun et al. 1994). The profile used for amplification was as described in Galbany-Casals et al. $(2004 a)$. Double-stranded PCR products were purified with either a QIAquick Purification Kit (Qiagen, Valencia, CA) or DNA Clean and Concentrator-5 (Zymo Research, Orange, CA) and sequenced with the same primers. Direct sequencing of the amplified DNA segments was performed with a Big Dye Terminator v3.1 kit (Applied Biosystems, Foster City, CA), following the protocol recommended by the manufacturer. 
Nucleotide sequencing was carried out at the Serveis CientíficoTècnics of the University of Barcelona on an ABI PRISM 3700 DNA analyzer (Applied Biosystems). In all cases, only one PCR product was obtained, and direct sequencing produced generally unambiguous sequences. For that reason, no species was cloned for ITS. However, a few double peaks appeared in some chromatograms, and these were coded with ambiguous bases, although we cannot be sure whether they are noise or genuine variation, given that we did not clone them.

\section{nrDNA ETS Region Strategies}

The ETS DNA region was amplified using the forward primer ETS1f (Linder et al. 2000) and the reverse primer 18S-2L (Linder et al. 2000) or 18S-ETS (Markos and Baldwin 2001). In some cases, Ast- 1 and Ast- 2 were also used as internal primers (Markos and Baldwin 2001). The profile used for amplification included a 5 -min denaturing at $95^{\circ} \mathrm{C}$, followed by 30 cycles of $94^{\circ} \mathrm{C}$ denaturing for $45 \mathrm{~s}, 48^{\circ} \mathrm{C}$ annealing for $45 \mathrm{~s}$, and $72^{\circ} \mathrm{C}$ extension for $40 \mathrm{~s}$, with an additional 7 $\min$ at $72^{\circ} \mathrm{C}$. Purification and sequencing was performed as for the ITS region, but with the corresponding primers. In all cases, only one PCR product was obtained, and all but five ETS sequences could be obtained by direct sequencing. When a possible polymorphism was observed in some positions of the ETS sequences obtained by direct sequencing, nucleotides were replaced with ambiguous bases, although they are interpreted as noise rather than as genuine variation because these ambiguous positions were mainly found at the end of the sequence or in the internal primers' annealing zone.

Direct sequences could not be obtained for five species: $H$. oligocephalum DC., H. crassifolium (L.) D. Don, H. pallasii (Spreng.) Ledeb., H. thianschanicum Regel, and H. graveolens (M. Bieb.) Sweet. In these cases, the ETS PCR product was cloned by using a TOPO TA Cloning kit (Invitrogen, Carlsbad, CA) according to the manufacturer's instructions, except that only half-reactions were used. When available, eight positive colonies from each reaction were screened with direct PCR and the T7 and M13R universal primers, according to the amplification profile described in Vilatersana et al. (2007). All PCR products obtained were the same size. Finally, four PCR products for each species, when possible, were selected randomly for sequencing in both directions with the same primers.

All sequences obtained for each cloned species were included in a first analysis. When multiple sequences of the same species formed a highly supported monophyletic group and sequence dissimilarity was low $(H$. pallasii, $H$. thianschanicum, and $H$. graveolens), a consensus sequence was generated for subsequent analyses. This was done by replacing nucleotides at polymorphic positions with ambiguous bases in the consensus sequence. This strategy was chosen to include all available data potentially contributing to the phylogeny construction. Also, this reduced the size of the matrices as well as the effect of potential PCR artifacts (chimerical sequences and Taq errors; Cline et al. 1996; Popp and Oxelman 2001). When multiple sequences of the same species did not form a highly supported monophyletic group, all sequences were used in final analyses.

\section{Analyses}

Nucleotide sequences were edited with Chromas 2.0 (Technelysium, Tewantin, Australia) and aligned visually by sequential pairwise comparison (Swofford and Olsen 1990). Data matrices are available on request from the corresponding author.

The evolutionary relationships in Helichrysum were examined for four data sets. Data set 1 consisted of ITS sequences of 95 species, including 90 Helichrysum species and five species from other genera. In analyses using data set 1, Anaxeton laeve, Syncarpha mucronata, Helichrysum dasyanthum, and Plecostachys serpyllifolia were coded as outgroup taxa. A subset of data set 1 was used to construct data sets 2-4. This subset, which was the main objective of our study, contained the Asiatic, Macaronesian, and Mediterranean Helichrysum species that constituted a derived monophyletic clade in the analyses from data set 1 . Helichrysum milfordiae Killick and H. populifolium DC., two African species, were also included and were designated as outgroup taxa in the analyses of data sets 2-4. Data set 2 contained 43 ITS sequences of the same number of species; data set 3 contained 46 ETS sequences of the 43 species, because for some of the species several clones were included; and data set 4 was a combined ITS and ETS data set and contained 46 sequences corresponding to the 43 species. In this combined data set, for each cloned species, the same ITS sequence was repeated for each of the ETS clones.

A partition homogeneity test (incongruence length difference [ILD]; Farris et al. 1994) was carried out to test the heterogeneity of phylogenetic signal across the ITS and ETS data sets (data sets 2 and 3, respectively). This test (implemented in PAUP*, ver. 4.0b10; Swofford 2002) was accomplished by excluding uninformative characters and using heuristic search and a simple addition of taxa for 300 random partitions of the data.

Parsimony analyses of all data sets involved heuristic searches conducted with PAUP*, version 4.0b10 (Swofford 2002), using tree bisection reconnection (TBR) branch swapping with character states specified as unordered and unweighted. The indels were not excluded from analyses and were coded as missing data. All most parsimonious trees (MPTs) were saved, except in the case of the data set 1 analysis, in which only 500 trees were held at each step to minimize the time of search. To locate other potential islands of MPTs (Maddison 1991), we performed 1000 replications with random taxon addition, also with TBR branch swapping. Bootstrap (BS) analyses (Felsenstein 1985) were performed with 100 replications and heuristic search with the default options, except for data set 1 analysis, which followed the approach of Lidén et al. (1997), using 1000 replicates, random taxon addition with 20 replicates, and no branch swapping. For the parsimony analyses, consistency index (CI), retention index (RI), and homoplasy index (HI) are given (table 1), excluding uninformative characters.

Bayesian inference (BI) estimation was calculated with MrBayes 3.1.2 (Huelsenbeck and Ronquist 2001; Ronquist and Huelsenbeck 2003). The best available model of molecular evolution, required for Bayesian estimations of phylogeny, was selected using hierarchical likelihood ratio tests (hLRT) and the Akaike Information Criteria (AIC; Akaike 1973), as 
Table 1

Main ETS and ITS Sequence Characteristics and Analysis Results for the Different Data Sets

\begin{tabular}{|c|c|c|c|c|}
\hline & Data set 1 & Data set 2 & Data set 3 & Data set 4 \\
\hline No. of taxa & 95 & 43 & 46 & 46 \\
\hline Aligned length & 503 & 479 & 1151 & 1630 \\
\hline No. of gaps & 40 & 12 & 15 & 27 \\
\hline Gap length range (bp) & $1-45$ & 1 & $1-291$ & $1-291$ \\
\hline No. of variable sites & 248 & 88 & 264 & 352 \\
\hline No. of sites with missing data & 0 & 0 & 12 & 12 \\
\hline No. of ambiguous/polymorphic sites & 15 & 5 & 57 & 62 \\
\hline \multicolumn{5}{|l|}{ Parsimony analyses: } \\
\hline Parsimony-informative characters & 143 & 32 & 120 & 153 \\
\hline No. of most parsimonious trees & 390,500 & 160 & 18,892 & 660 \\
\hline No. of steps & 497 & 56 & 231 & 295 \\
\hline Consistency index & .4708 & .6429 & .6623 & .6475 \\
\hline Retention index & .7882 & .8540 & .8770 & .8670 \\
\hline Homoplasy index & .5292 & .3571 & .3377 & .3525 \\
\hline \multicolumn{5}{|l|}{ Bayesian inference: } \\
\hline Model of molecular evolution & GTR $+\Gamma$ & GTR $+\Gamma$ & $\mathrm{GTR}+\Gamma$ & $\mathrm{GTR}+\Gamma$ \\
\hline
\end{tabular}

Note. Data set 1 includes ITS sequences of all species studied. Data set 2 contains ITS sequences of the Asiatic, Macaronesian, and Mediterranean Helichrysum species that constituted a derived monophyletic clade in the analyses from data set 1, with Helichrysum milfordiae and H. populifolium as outgroup taxa. Data set 3 contains ETS sequences for the species in data set 2. Data set 4 combines data sets 2 and 3 . The consistency, retention, and homoplasy indices are calculated excluding uninformative characters.

implemented in MrModeltest 2.2 (Nylander 2004), which considers only nucleotide substitution models that are currently implemented in PAUP and MrBayes 3.1.2. For all data sets, the General Time-Reversible model (Rodríguez et al. 1990) with variable sites assumed to follow a discrete gamma distribution (GTR $+\Gamma$; Yang 1996) was identified as the bestfitting symmetrical model for the sequence data by both the hLTR and the AIC statistics, so GTR $+\Gamma$ was the model used in all analyses. Phylogenetic reconstruction using BI was performed with MrBayes 3.1.2. Two simultaneous and independent analyses were performed; for each analysis, four Markov Monte Carlo chains were run simultaneously, starting from random trees. Each analysis was run for 1,000,000 generations and sampled one of every 100 generations, which resulted in 20,000 sample trees. A critical aspect of the Bayesian analysis is to ensure that the Markov chain has reached stationarity. With this aim, the first 1000 trees (burn-in) were excluded before the majority-rule consensus tree was computed, to avoid trees that might have been sampled before convergence of the Markov chains. Posterior probability support (PP) was estimated to be significant for nodes with PP $>0.95$.

\section{Results}

Numeric results of main sequence characteristics for each data set are summarized in table 1.

\section{Size and Composition of ITS}

In data set 1, the length of the ITS1 region in the studied taxa ranged from 213 bp in Helichrysum lambertianum DC. to $260 \mathrm{bp}$ in $H$. simillinum DC. The ITS2 region ranged from $217 \mathrm{bp}$ in $H$. acutatum DC. to $228 \mathrm{bp}$ in Anaxeton laeve. Within Helichrysum, H. confertum N. E. Br. had the longest ITS2 region, with $223 \mathrm{bp}$. In data set 2, the length of the ITS1 region in the studied taxa ranged from 253 bp in $H$. sanguineum (L.) Kostel. to $256 \mathrm{bp}$ in $H$. milfordiae and H. populifolium. The ITS2 region was 218 bp long in H. leucocephalum Boiss. and $219 \mathrm{bp}$ long in the other species.

Sequence divergence was calculated separately for the ITS1 and ITS2 regions with the distance matrix option available in PAUP. ITS1 sequence divergence within data set 1 varied from $0 \%$ (between 53 pairs of species of Helichrysum) to $16.05 \%$ (pairwise distance between H. monogynum and Syncarpha mucronata). ITS1 sequence divergence within data set 2 varied from $0 \%$ (between 53 pairs of species of Helichrysum) to $6.67 \%$ (pairwise distance between $H$. thianschanicum and $H$. populifolium). ITS2 sequence divergence within data set 1 varied from $0 \%$ (between 75 pairs of species of Helichrysum) to $14.87 \%$ (pairwise distance between $H$. retortum [L.] Willd. and Castroviejoa montelinasana). ITS2 sequence divergence within data set 2 varied from $0 \%$ (between 74 pairs of species of Helichrysum) to $11.01 \%$ (pairwise distance between $H$. pamphylicum Davis \& Kupicha and H. populifolium).

Ambiguous positions in ITS sequences were very scarce (table 1). Since no ITS sequences were cloned, we cannot be sure whether they are due to noise or to genuine variation.

\section{Size and Composition of ETS}

The length of the ETS portion used (data set 3) ranged from 837 bp in $H$. arenarium (L.) Moench ssp. arenarium, $H$. arenarium ssp. aucheri (Boiss.) P. H. Davis \& Kupicha, H. lacteum Coss. \& Durieu, $H$. graveolens, and $H$. artemisioides Boiss. \& Hausskn. to 1112 bp in H. milfordiae. ETS sequence divergence was calculated with the distance matrix option available in PAUP. It varied from $0.12 \%$ (pairwise distance between $H$. doerfleri Rech. f. and $H$. amorginum Boiss. \& Orph.) to $9.77 \%$ (pairwise distance between one of the clones of $H$. oligocephalum and $H$. milfordiae). 
Direct ETS sequences could not be obtained for five species: H. oligocephalum, H. crassifolium, H. pallasii, H. thianschanicum, and $H$. graveolens, and these were cloned. The different clones obtained for each of the last three species formed highly supported monophyletic clades because of high sequence similarity: the clones of $H$. pallasii presented only five polymorphic positions, those of $H$. thianschanicum only three, and those of $H$. graveolens only one. Therefore, they are represented by a single consensus sequence in the final phylogenetic trees (figs. 4, 5). The cases of $H$. crassifolium and $H$. oligocephalum are different: the ETS clones obtained for both of these species did not form monophyletic groups and presented notable levels of polymorphism: the clones of $H$. oligocephalum presented 27 polymorphic positions and those of $H$. crassifolium 13.

\section{Phylogenetic Analyses}

The numerical results of the analyses with all data sets are given in table 1 . Both parsimony and BI analyses showed highly congruent topologies for each data set. Therefore, for each data set, we discuss only one of the analyses, either the BI or the parsimony strict consensus tree. However, BS values from the parsimony analysis and Bayesian PP are shown in all figures.

In the analyses of data set 1 (fig. 3), the species of Helichrysum coded as ingroup are monophyletic ( $\mathrm{BS}=100 \%, \mathrm{PP}=1)$. Castroviejoa frigida and C. montelinasana constitute a clade $(\mathrm{BS}=100 \%, \mathrm{PP}=1$; fig. 3 ) that is excluded from the Helichrysum group and placed in the outgroup. Within the Helichrysum clade, the southern African $H$. retortum, $H$. lambertianum, $H$. asperum (Thunb.) Hilliard \& B. L. Burtt, and H. spiralepis Hilliard \& B. L. Burtt form a basal polytomy. Many African Helichrysum appear in a general polytomy, and the few clades moderately supported include mixed tropical and southern African species. However, some results are worthy of comment. Helichrysum monogynum and H. alucense, from the Canary Islands, are grouped together $(\mathrm{BS}=99 \%, \mathrm{PP}=1$; fig. 3) with $H$. makranicum, from Oman and southern Iran, as sister taxa (BS $=100 \%, \mathrm{PP}=1$ ), with H. populifolium, from South Africa, as sister to this three-species clade ( $\mathrm{BS}=55 \%, \mathrm{PP}=0.97$ ). Within the general Helichrysum clade, another highly supported clade is observed that includes all the Mediterranean and western and central Asiatic species and most of the Macaronesian ones (excluding $H$. monogynum and $H$. alucense; $\mathrm{BS}=98 \%$, $\mathrm{PP}=1)$.

The analyses from data sets 2 and 3 provided congruent phylogenies (fig. 4). Low general resolution and the absence of any supported incongruence justified combination of the ITS and ETS data sets. The result of the ILD test was $P=0.3$, which meant that both data sets contained highly congruent phylogenetic signals and supported the possibility of combining the two regions.

The ETS alone (data set 3 ) provided most of the resolution and support of the internal nodes in the MediterraneanAsiatic-Macaronesian group (fig. 4), although the combined ITS-ETS analyses (data set 4) showed the highest overall support values, for which we discuss the following results (see fig. 5). Within the Mediterranean-Asiatic-Macaronesian clade, the four Madeiran endemic species constitute a monophyletic group ( $\mathrm{BS}=100 \%, \mathrm{PP}=1$; fig. 5 , clade $\mathrm{E}$ ) sister to the rest of the species, which also constitute a monophyletic group (BS $=100 \%, P P=1)$. Helichrysum gossypinum, from Lanzarote, is sister to the whole Mediterranean-Asiatic group (BS $=87 \%, P P=1$ ), according to our sampling. Internal relationships within the Mediterranean-Asiatic group are much better resolved than those in the previous study using ITS alone (Galbany-Casals et al. 2004a). In this clade, two main groups sister to each other are highly supported: a clade that includes all the species of sect. Stoechadina $(\mathrm{BS}=100 \% ; \mathrm{PP}=1$; fig. 5, clade C) and another that comprises all the representatives of sect. Helichrysum and sect. Virginea (BS $=99 \%$, $\mathrm{PP}=1$; fig. 5, clades A, B). Sections Virginea and Helichrysum do not form monophyletic groups, because representatives of sect. Virginea are scattered among representatives of sect. Helichrysum.

\section{Discussion}

\section{Utility of ETS and Congruence between ITS and ETS Phylogenies}

The ETS is longer than ITS1 and ITS2 together, and it provides at least as many variable and potentially informative sites than the ITS in this and other studies (Baldwin and Markos 1998; Bena et al. 1998; Linder et al. 2000; Andreasen and Baldwin 2003). In our case, in the ITS $6.68 \%$ of the characters are informative, while in the ETS the percentage is $10.43 \%$, which represents a ratio of 1.5 . However, we used nearly the entire ETS region, including the $5^{\prime}$ portion, which is generally more variable than the $3^{\prime}$ portion, and in our case it was easily aligned because of high sequence similarity. In ETS alignment, most of gaps were 1-5 bp, and only one large gap (291 bp) was needed in the alignment of H. populifolium and $H$. milfordiae with the Mediterranean-Asiatic-Macaronesian group. In contrast, nearly all studies use only the $3^{\prime}$ portion because of the general difficulties in aligning the too-variable $5^{\prime}$ end.

As they are parts of the same transcriptional unit, the ITS and ETS regions are said to be evolving under similar functional constraints and at comparable rates (Baldwin and Markos 1998). ITS and ETS phylogenies are usually congruent and combinable, so that the ETS becomes a source of additional characters for increasing resolution and support in nrDNA-based phylogenies (Baldwin and Markos 1998). However, Okuyama et al. (2005) caution that sometimes the ITS and the ETS can provide incongruent phylogenies because of uneven rates of concerted evolution after introgressive hybridization. In our case, the ITS and ETS data are highly congruent (fig. 4).

Okuyama et al. (2005) stated that sequence heterogeneity within an individual is a good indicator of the extent to which concerted evolution has progressed. In Helichrysum, a few species contained different ETS sequences, suggesting that concerted evolution is not complete in these cases. Several factors could be the cause for sequence polymorphism, such as incomplete lineage sorting, a high mutation rate relative to the rate of concerted evolution, and hybridization (Andreasen and Baldwin 2003). We can discuss only the polymorphism observed in the cloned species, because the cause of ambiguous bases in sequences not cloned may be either genuine variation or noise. The five species cloned for this study 


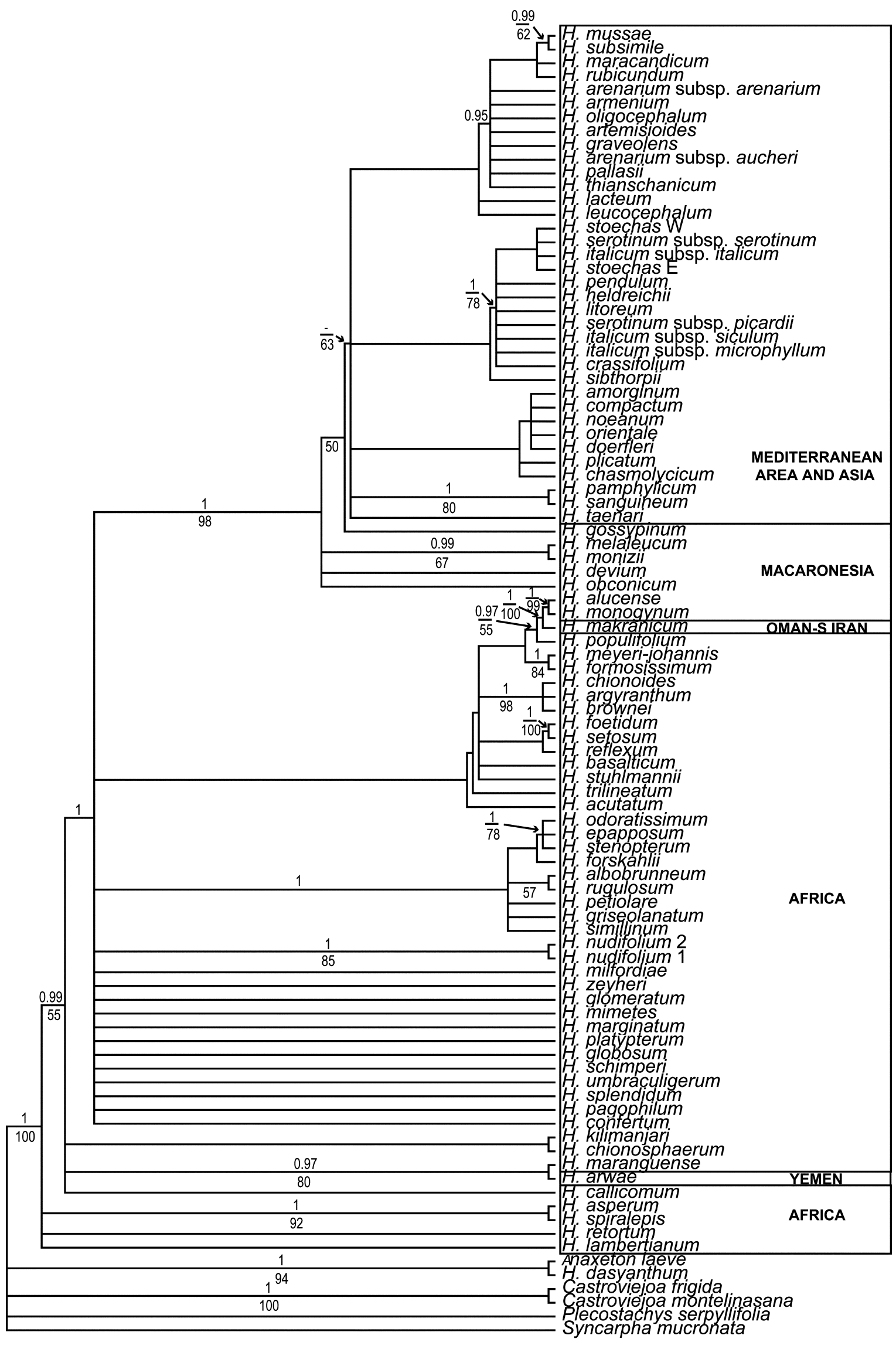



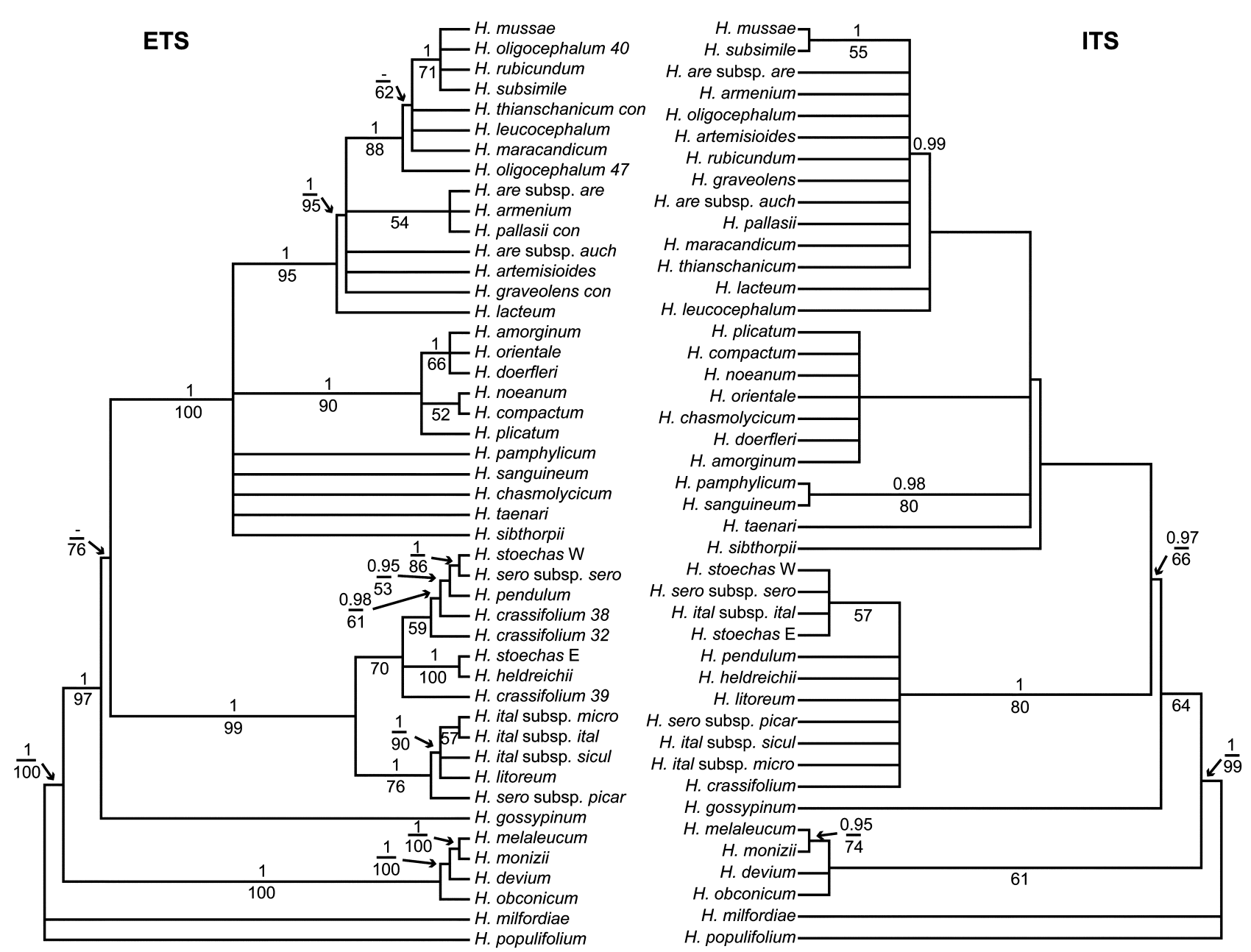

Fig. 4 Left, strict consensus tree of the 18,892 equally most parsimonious trees obtained in the parsimony analysis of ETS sequences for the Mediterranean-Asiatic-Macaronesian group (data set 3). Right, strict consensus tree of the 160 equally most parsimonious trees obtained in the parsimony analysis of ITS sequences for the same group (data set 2). Bayesian posterior probabilities $\geq 0.95$ are shown above branches, and bootstrap values $>50 \%$ from the parsimony analyses are shown below branches. Taxon abbreviations: are $=$ arenarium; auch $=$ aucheri; con $=$ consensus sequence; ital $=$ italicum; micro $=$ microphyllum; picar $=$ picardii; sero $=$ serotinum sicul $=$ siculum .

presented some degree of polymorphism, but the cases of $H$. crassifolium and $H$. oligocephalum are the most interesting because both presented many more polymorphic positions than the other three species and because the ETS clones obtained for each species did not form monophyletic groups. We believe that, in both cases, besides the lack of complete concerted evolution, these results probably show hybridization and introgression with other species. In particular, the sequenced specimen of $H$. crassifolium was collected by two of the authors near populations of $H$. pendulum (C. Presl) C. Presl, and putative hybrid specimens between these two species have been reported on the basis of morphology (GalbanyCasals et al. 2006). The comparison of sequences obtained for both species also seems to support our hybridization hypoth- esis: although the three clones of $H$. crassifolium are invariable in several positions where $H$. pendulum differs, in the positions where the clones are polymorphic there is always one of the multiple nucleotides that coincides with the one that $H$. pendulum has (table 2). The case of H. oligocephalum deserves some comments as well. This species overlaps in distribution area with $H$. rubicundum (K. Koch) Bornm. and $H$. leucocephalum in Iran, and the three specimens of these species that we have sequenced came from Iran. The variable sites of $H$. rubicundum, $H$. leucocephalum, and the two clones of $H$. oligocephalum are compared in table 3. Although definite conclusions cannot be drawn about hybridization, we can appreciate that the clone $H$. oligocephalum 40 is notably similar to $H$. rubicundum, while the clone $H$. oligocephalum 47

Fig. 3 Consensus tree obtained from the Bayesian analysis of ITS sequences (data set 1). Bayesian posterior probabilities $\geq 0.95$ are shown above branches, and bootstrap values $>50 \%$ from the parsimony analyses are shown below branches. 


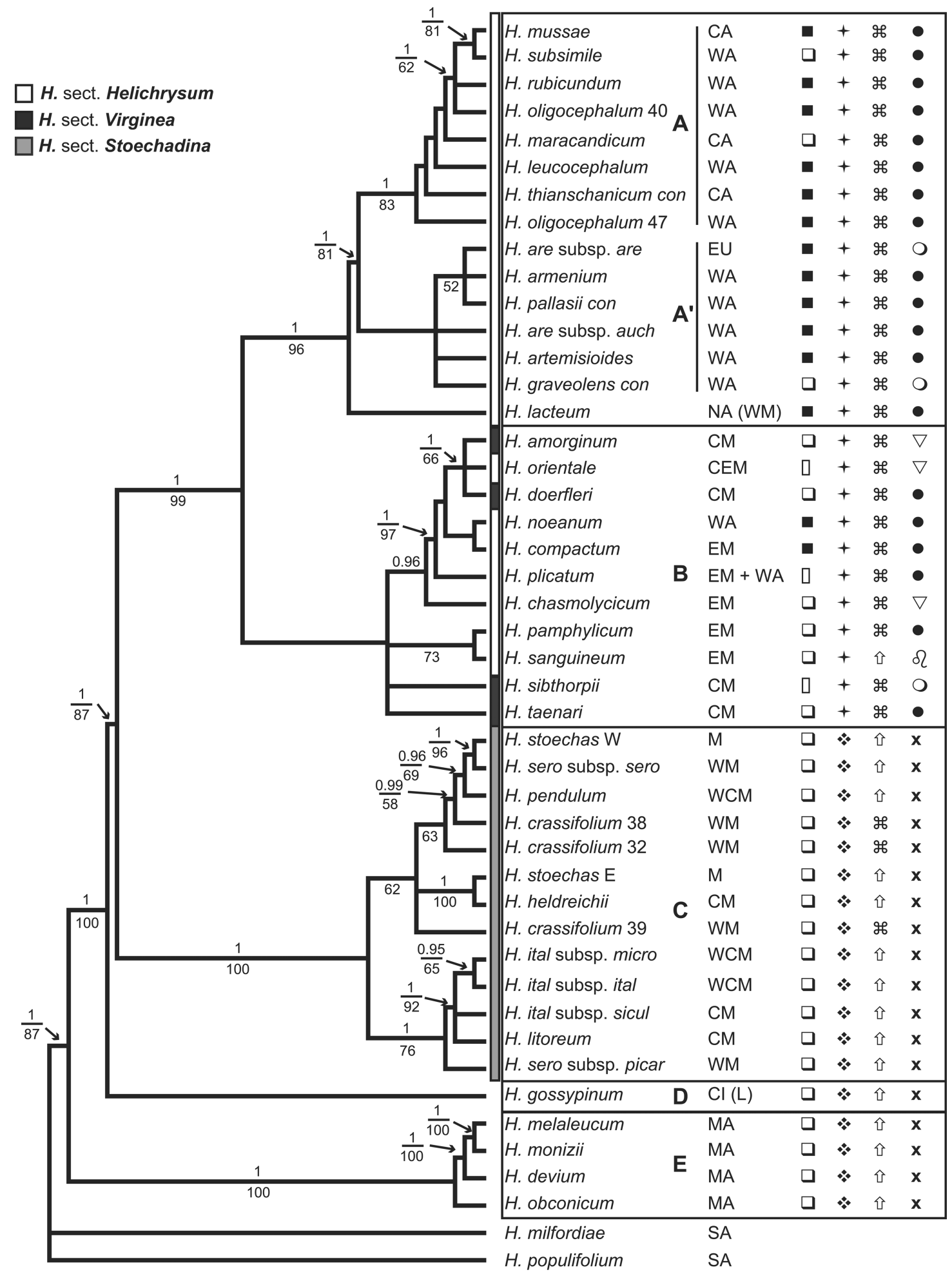

Fig. 5 Consensus tree obtained from the Bayesian analysis of the combined ITS-ETS sequences data set (data set 4). Bayesian posterior probabilities $\geq 0.95$ are shown above branches, and bootstrap values $>50 \%$ from the parsimony analyses are shown below branches. Region acronyms: $C A=$ central Asia; $C I=$ Canary Islands; $C E M=$ central and eastern Mediterranean; $C M=$ central Mediterranean; $E M=$ eastern Mediterranean; $E U=$ Eurasia; $L=$ Lanzarote; $M=$ Mediterranean; $M A=$ Madeira Islands; $N A=$ North Africa; $S A=$ southern Africa; $W A=$ western Asia; $W C M=$ western and central Mediterranean; $W M=$ western Mediterranean. Taxon abbreviations: are $=$ arenarium; auch $=$ aucheri; con $=$ consensus sequence; ital $=$ italicum; micro = microphyllum; picar = picardii; sero $=$ serotinum; sicul $=$ siculum. Morphological characters: open square $=$ capitula heterogamous; filled square $=$ capitula homogamous; rectangle $=$ capitula heterogamous or homogamous; diamonds $=$ shrubs or 
Table 2

Summary of the Nucleotide Site Variation in ETS Sequences among Helichrysum pendulum and the Clones of $\boldsymbol{H}$. crassifolium

\begin{tabular}{lcccc}
\hline & $\begin{array}{c}\text { H. } \\
\text { pendulum }\end{array}$ & $\begin{array}{c}\text { H. } \\
\text { crassifolium } 39\end{array}$ & $\begin{array}{c}\text { H. } \\
\text { crassifolium } 38\end{array}$ & $\begin{array}{c}H . \\
\text { crassifolium } 32\end{array}$ \\
\hline 16 & $\mathrm{G}$ & $\mathrm{G}$ & $\mathrm{G}$ & $\mathrm{A}$ \\
42 & $\mathrm{~A}$ & $\mathrm{G}$ & $\mathrm{A}$ & $\mathrm{A}$ \\
53 & $\mathrm{G}$ & $\mathrm{T}$ & $\mathrm{T}$ & $\mathrm{T}$ \\
125 & $\mathrm{C}$ & $\mathrm{C}$ & $\mathrm{C}$ & $\mathrm{G}$ \\
167 & $\mathrm{~A}$ & $\mathrm{G}$ & $\mathrm{A}$ & $\mathrm{A}$ \\
202 & $\mathrm{C}$ & $\mathrm{T}$ & $\mathrm{T}$ & $\mathrm{T}$ \\
603 & $\mathrm{~T}$ & $\mathrm{~T}$ & $\ldots$ & $\ldots$ \\
661 & $\mathrm{~A}$ & $\mathrm{~T}$ & $\mathrm{~A}$ & $\mathrm{~T}$ \\
663 & $\mathrm{C}$ & $\mathrm{T}$ & $\mathrm{T}$ & $\mathrm{T}$ \\
687 & $\mathrm{~T}$ & $\mathrm{~T}$ & $\mathrm{~T}$ & $\mathrm{C}$ \\
765 & $\mathrm{C}$ & $\mathrm{C}$ & $\mathrm{T}$ & $\mathrm{C}$ \\
769 & $\mathrm{G}$ & $\mathrm{A}$ & $\mathrm{G}$ & $\mathrm{G}$ \\
771 & $\mathrm{~T}$ & $\mathrm{C}$ & $\mathrm{T}$ & $\mathrm{T}$ \\
783 & $\mathrm{~A}$ & $\mathrm{~A}$ & $\mathrm{~A}$ & $\mathrm{G}$ \\
918 & $\mathrm{~A}$ & $\mathrm{~T}$ & $\mathrm{~A}$ & $\mathrm{~A}$ \\
1106 & $\mathrm{~T}$ & $\mathrm{C}$ & $\mathrm{T}$ & $\mathrm{T}$ \\
\hline
\end{tabular}

presents some exclusive nucleotides and is more similar to $H$. leucocephalum than to H. rubicundum.

\section{Taxonomic Implications}

Our ITS phylogeny clearly shows the independence of the two Mediterranean species Castroviejoa frigida and Castroviejoa montelinasana, traditionally classified under the genus Helichrysum, from the Mediterranean Helichrysum species and even from the entire genus Helichrysum, as they are placed with the outgroup taxa. In addition, our results demonstrate the close relationship between these two species, as they are grouped together with very high support.

Within the Mediterranean and Asiatic Helichrysum, a clear monophyletic group was resolved (fig. 5, clade C) that includes all the species recently considered, on the basis of morphological evidence, to constitute sect. Stoechadina (Galbany-Casals et al. 2006). They are all shrubs or subshrubs. They never have conspicuous resting buds, stolons, or rhizomes, and only $H$. crassifolium has leaf rosettes. All have heterogamous capitula and are tetraploid $(2 n=28)$. However, within this section, some results of the ETS phylogeny show incongruence with the morphology: some taxa of close geographic origin that are morphologically distinct are grouped together. First, the two specimens of H. stoechas (L.) Moench do not appear in a monophyletic clade. We think that the specimen $H$. stoechas $\mathrm{E}$, from Crete, could have undergone recent hybridization with $H$. heldreichii Boiss., also from Crete, not detectable from the morphology, and that this would explain why they appear in a highly supported monophyletic clade (ETS: BS $=100 \%$, $\mathrm{PP}=1$; ETS-ITS: $\mathrm{BS}=100 \%, \mathrm{PP}=1$; figs. 4 and 5 , respec- tively). Second, H. serotinum (DC.) Boiss. ssp. serotinum does not form a group with $H$. serotinum ssp. picardii (Boiss. \& Reut.) Galbany, L. Sáez \& Benedí but does form one with $H$. stoechas W, from Spain (ETS: BS $=86 \%, \mathrm{PP}=1$; ETS-ITS: $\mathrm{BS}=96 \%, \mathrm{PP}=1$; figs. 4 and 5, respectively). Again, recent hybridization events may be the cause of our results, because potential hybrids between $H$. stoechas and $H$. serotinum have been reported on the basis of morphology (Galbany-Casals et al. 2006) and because the sequenced specimen of $H$. serotinum ssp. serotinum was growing close to populations of $H$. stoechas. Other cases of conflict among morphological and molecular data have been used by authors as a demonstration of reticulate evolution (Fuertes Aguilar et al. 1999; Comes and Abbott 2001; Andreasen and Baldwin 2003; Suárez-Santiago et al. 2007). Gene flow between sympatric species may allow geographical structuring (Fuertes Aguilar et al. 1999; Nieto Feliner et al. 2004), detectable from the similarity or sharing of their ITS and/or ETS sequences.

Species traditionally classified in $H$. sect. Virginea were not grouped together in the phylogeny but appeared scattered in the clade of eastern Mediterranean representatives of sect. Helichrysum (fig. 5, clade B). On the one hand, the positions of $H$. taenari and $H$. sibthorpii were not resolved in any of the analyses. On the other hand, H. amorginum and H. doerfleri constituted a moderately supported clade with $H$. orientale (L.) Gaertn. from sect. Helichrysum (BS $=66 \%$, PP $=1$; fig. 5).

Relationships observed within sect. Helichrysum and sect. Virginea are correlated with geographic distribution rather than with any infrageneric treatment. Although internal nodes were not strongly supported, we can recognize two main clades, the first comprising species mainly distributed in the eastern Mediterranean region ( $\mathrm{BS}<50 \%, \mathrm{PP}=0.82$; fig. 5, clade $\mathrm{B}$ ) and the second comprising species mainly distributed in Asia ( $\mathrm{BS}=96 \%, \mathrm{PP}=1$; fig. 5, clade A). However, there are two exceptions to this pattern: H. noeanum Boiss. is endemic to inner Turkey but appears within the eastern Mediterranean clade, and H. lacteum is endemic to northern Africa but appears at the base of the western Asia-central Asia clade with high support $\left(\mathrm{BS}=95 \%, \mathrm{PP}=1\right.$; fig. 5, clades $\mathrm{A}$ and $\mathrm{A}^{\prime}$, respectively). Within the Asiatic clade resolution is poor, and species from western and central Asia are intermixed. However, all the species endemic to central Asia-H. mussae Nevski, H. maracandicum Popov ex Kirp., and H. thianschanicum-are in the same clade (fig. 5, clade A).

\section{Character Evolution}

Regarding habit, the species of the Mediterranean sect. Stoechadina share with H. gossypinum and the four species endemic to Madeira, which are basal, a shrubby habit and the lack of rosettes and overwintering buds (fig. 1A). In contrast, species from the eastern Mediterranean basin and western and central Asia are predominantly caespitose-suffruticose, with rosettes and often with conspicuous overwintering buds (fig. 1B). Therefore, within the Mediterranean-Asiatic Helichry-

subshrubs, vegetative stems well developed, plants in general without leaf rosettes; plus signs = suffruticose plants, vegetative stems usually short, plants in general with leaf rosettes; arrow $=$ leaf rosettes absent; cloverleaf $=$ leaf rosettes present; cross $=$ resting buds absent; open circle $=$ resting buds not conspicuous; filled circle $=$ resting buds conspicuously swollen; triangle $=$ resting buds not conspicuous or conspicuously swollen; "tadpole" $=$ resting buds subterraneous. 
Table 3

Summary of the Nucleotide Site Variation in ETS Sequences among Helichrysum rubicundum, $\boldsymbol{H}$. leucocephalum, and the Clones of $\boldsymbol{H}$. oligocephalum

\begin{tabular}{|c|c|c|c|c|}
\hline & $\begin{array}{c}H . \\
\text { leucocephalum }\end{array}$ & $\begin{array}{c}H . \\
\text { rubicundum }\end{array}$ & $\begin{array}{c}H . \\
\text { oligocephalum } \\
40\end{array}$ & $\begin{array}{c}H . \\
\text { oligocephalum } \\
47\end{array}$ \\
\hline 42 & A & A & G & G \\
\hline 53 & $\mathrm{~T}$ & C & $\mathrm{T}$ & $\mathrm{T}$ \\
\hline 102 & A & $\mathrm{T}$ & A & A \\
\hline 199 & G & $\mathrm{T}$ & $\mathrm{T}$ & $\mathrm{T}$ \\
\hline 203 & G & G & G & A \\
\hline 204 & K & G & G & $\mathrm{T}$ \\
\hline 205 & $\mathrm{~K}$ & $\mathrm{~T}$ & $\mathrm{~T}$ & G \\
\hline 206 & $\mathrm{~T}$ & $\mathrm{~T}$ & $\mathrm{~T}$ & G \\
\hline 526 & $\mathrm{~T}$ & $\mathrm{~T}$ & A & $\mathrm{T}$ \\
\hline 528 & A & $\mathrm{T}$ & $\mathrm{T}$ & A \\
\hline 533 & $\overline{\mathrm{G}}$ & $\overline{\mathrm{A}}$ & $\overline{\mathrm{A}}$ & $\overline{\mathrm{A}}$ \\
\hline 582 & A & A & A & G \\
\hline 587 & A & A & A & $\mathrm{G}$ \\
\hline 591 & $\mathrm{~T}$ & $\mathrm{~T}$ & C & $\mathrm{T}$ \\
\hline 595 & $\mathrm{~T}$ & $\mathrm{~T}$ & $\mathrm{C}$ & $\mathrm{T}$ \\
\hline 604 & A & A & A & $\mathrm{T}$ \\
\hline 608 & A & $\mathrm{G}$ & A & A \\
\hline 612 & $\mathrm{~T}$ & G & G & $\mathrm{T}$ \\
\hline 622 & $\overline{\mathrm{C}}$ & $\overline{\mathrm{A}}$ & $\overline{\mathrm{A}}$ & $\overline{\mathrm{C}}$ \\
\hline 647 & $\overline{\mathrm{A}}$ & $\overline{\mathrm{G}}$ & $\overline{\mathrm{G}}$ & $\overline{\mathrm{G}}$ \\
\hline 662 & $\mathrm{~T}$ & $\mathrm{~T}$ & $\mathrm{~T}$ & $\mathrm{C}$ \\
\hline 663 & $\ldots$ & $\ldots$ & $\ldots$ & $\mathrm{T}$ \\
\hline 684 & G & G & $\mathrm{G}$ & $\mathrm{T}$ \\
\hline 699 & A & G & G & G \\
\hline 707 & $\mathrm{G}$ & $\mathrm{G}$ & $\mathrm{G}$ & $\mathrm{T}$ \\
\hline 713 & $\mathrm{~T}$ & $\mathrm{~T}$ & $\mathrm{C}$ & $\mathrm{T}$ \\
\hline 735 & A & $\mathrm{G}$ & G & G \\
\hline 742 & $\mathrm{G}$ & $\mathrm{G}$ & A & G \\
\hline 751 & A & A & A & $\mathrm{C}$ \\
\hline 881 & $\ldots$ & $\ldots$ & $\mathrm{T}$ & $\mathrm{T}$ \\
\hline 883 & $\mathrm{~T}$ & $\mathrm{~T}$ & & $\ldots$ \\
\hline 910 & $\mathrm{~T}$ & $\mathrm{~T}$ & $\mathrm{C}$ & $\mathrm{T}$ \\
\hline 939 & $\mathrm{C}$ & $\mathrm{C}$ & $\mathrm{C}$ & $\mathrm{T}$ \\
\hline 1032 & $\mathrm{C}$ & $\mathrm{C}$ & $\mathrm{C}$ & $\mathrm{T}$ \\
\hline 1052 & $\mathrm{~T}$ & $\mathrm{~T}$ & $\mathrm{~T}$ & $\mathrm{C}$ \\
\hline 1086 & $\mathrm{G}$ & A & A & G \\
\hline 1094 & $\overline{\mathrm{C}}$ & $\overline{\mathrm{C}}$ & $\overline{\mathrm{C}}$ & $\overline{\mathrm{T}}$ \\
\hline 1116 & C & G & G & G \\
\hline
\end{tabular}

Note. Underlining marks positions where H. oligocephalum 40 coincides with $H$. rubicundum and $H$. oligocephalum 47 coincides with H. leucocephalum.

sum clade, evolutionary trends may have led to a reduction in woodiness that is likely related to a change from a chamaephyte to a hemicryptophyte life form. The presence of rosettes and overwintering buds, conspicuous or not, seems to be related to the latter life form. Moreover, most of these caespitosesuffruticose species with overwintering buds grow in high mountain meadows or steppes in Turkey, the Transcaucasus, Iran, and central Asia, often at altitudes of more than $2000 \mathrm{~m}$. Several authors have reported the predominance of hemicryptophytes in high mountain environments (Körner 1999; Illa et al. 2006). The acquisition of this hemicryptophyte growth form may have permitted adaptation to high-mountain climatic con- ditions, particularly very cold winters, and radiation and speciation within these habitats.

Another character worthy of comment is the capitulum gender ratio. Regarding this character, the Canary Island endemic $H$. gossypinum, the Madeiran species, and species of sect. Stoechadina group share the same state, i.e., heterogamous capitula. Within the eastern Mediterranean and Asiatic groups, species with heterogamous and homogamous capitula occur, although those with the latter predominate in the Asiatic group, while the former prevail in the eastern Mediterranean clade (fig. 5). On the basis of this observation, homogamous capitula may be derived within the Mediterranean-Asiatic Helichrysum.

\section{Biogeographic Implications}

Southern African origin and expansion throughout the African continent. Our results confirm that Helichrysum has a southern African origin, as four southern African species appear in a basal polytomy, sister to the rest of African species plus the Mediterranean-Asiatic clade: H. retortum, H. lambertianum, and the monophyletic pair H. asperum and H. spiralepis (fig. 3). Few other conclusions can be extracted from our results regarding African species, because many African Helichrysum appeared in a general polytomy. However, species from tropical Africa (H. kilimanjari Oliv., H. maranguense O. Hoffm., H. forskahlii (J. F. Gmel.) Hilliard \& B. L. Burtt, H. globosum, H. meyeri-johannis, H. schimperi, H. formosissimum, H. stublmannii O. Hoffm., H. argyranthum O. Hoffm., H. chionoides, and H. brownei S. Moore) appear scattered in the phylogeny and do not constitute a monophyletic group, which may indicate that several migration events from southern Africa to tropical Africa have taken place.

Geographic origin and multiple colonization of Macaronesia. Our results show that Helichrysum has reached the Macaronesian islands more than once, because Macaronesian species appear in independent clades. As the Canary Islands are oceanic in origin (Carracedo et al. 1998), long-distance dispersal is a prerequisite. Multiple colonizations of volcanic archipelagos are rare because of geographical isolation from continental sources. However, as the Canary Islands are relatively close to the African mainland, an active dispersal route between part of Macaronesia and Africa may exist (FranciscoOrtega et al. 1999). There are several documented examples of multiple colonizations of the Macaronesian archipelago, particularly of the Canary Islands (Francisco-Ortega et al. 1999; Cuénoud et al. 2000; Hess et al. 2000; Park et al. 2001; Fuertes-Aguilar et al. 2002; Percy and Cronk 2002). In the case of Helichrysum, the different ancestors of the present species in Macaronesia probably reached the islands through wind dispersion of the tiny $(\sim 1 \mathrm{~mm})$, light seeds.

With regard to origin, we have a clade, consisting of the four species endemic to Madeira (fig. 5), that is sister to $H$. gossypinum, endemic to Lanzarote, which in turn is sister to the whole Mediterranean-Asiatic group. These results suggest either (1) that one species colonized Madeira from Africa and originated the four present endemic species and that some founder species was dispersed from this region to the Canary Islands and the Mediterranean area, where it radiated from west to east; (2) that two independent radiations from a 
common, probably extinct, ancestor in North Africa may have occurred to Madeira and the Mediterranean basin and that some founder species was dispersed from Madeira to the Canary Islands, where it originated H. gossypinum; or (3) that three independent radiations from a common, probably extinct, ancestor in North Africa may have occurred to Madeira, the Canary Islands, and the Mediterranean basin. In fact, several species of sect. Stoechadina, such as $H$. stoechas, H. serotinum, and H. pendulum, are present in Morocco. We think that the second and third scenarios are much more probable than the first one, although some cases of back-dispersal from Macaronesia to the mainland have been reported (Aeonium: Mes and Hart 1996; Convolvulus: Carine et al. 2004; Tolpis: Park et al. 2001); thus, this possibility cannot be ruled out. Some works indicate that the Madeiran endemics have their origin in the Canary Islands (Pericallis: Panero et al. 1999; Crambe: Francisco-Ortega et al. 2002; Convolvulus: Carine et al. 2004; Genista tenera: Percy and Cronk 2002; Sonchus: Lee et al. 2005; Bystropogon: Trusty et al. 2005), while others indicate a different origin (Hedera: Vargas et al. 1999a; Olea: Hess et al. 2000; Tolpis: Park et al. 2001). Regardless of possible evolutionary histories, the fact is that the sister taxon of the Macaronesian-Mediterranean-Asiatic Helichrysum remains unknown, although it is clear that it must be of African origin. In general, molecular phylogenies show that Macaronesian groups are derived rather than basal when compared with closely related continental taxa (see numerous examples in Francisco-Ortega et al. 1997; Goodson et al. 2006), although some other exceptions to these results have been reported, for example, the Tenerife endemic Lavatera phoenicea Vent., which appears in a basal position of its group (Fuertes-Aguilar et al. 2002), the genus Argyranthemum, which appears basal to three other Mediterranean genera (FranciscoOrtega et al. 1997), and Tolpis azorica, basal to a clade that includes two continental species and two other island endemics (Park et al. 2001).

Furthermore, our results place the other two species from the Canary Islands in a different lineage, indicating two different introductions into these islands. Helichrysum alucense, endemic to La Gomera, and H. monogynum, endemic to Lanzarote, form a monophyletic group sister to $H$. makranicum, which grows in Oman and southern Iran; H. populifolium, from South Africa, is sister to this three-species clade (fig. 3). This finding could support the phytogeographical links between eastern Africa-southern Arabia and the Macaronesian islands hypothesized by Quézel (1978). The close relationships between Macaronesian and eastern African-Arabian taxa were considered evidence of a continuous flora present in northern Africa and the Mediterranean region in the late Miocene (Axelrod 1975; Quézel 1978; Sunding 1979). Many elements of this hypothetical continuous flora disappeared from several areas of North Africa after major climatic changes during the late Tertiary and the Quaternary (Axelrod 1975; Quézel 1978). Thus, in the case of Helichrysum, a common, presumably extinct, ancestor of $H$. makranicum, $H$. alucense, and $H$. monogynum may have had a more widespread distribution and/or reached the western part of northern Africa from eastern Africa through the Sahara region before desertification; from there it probably colonized the Canary Islands. The length of phylogram branches (not shown) suggests that the divergence in these two lineages must be quite ancient. Present-day Helichrysum species from the Canary Islands are not associated with sclerophyllouslauroid flora but with open shrubby or subshrubby communities. Their ancestor may have had similar ecological preferences, in which case its area expansion through northwestern Africa would likely have been along open patches within the lauroid forests. Alternatively, colonizers of the Canary Islands could have evolved their present ecological preferences as an adaptation to the island environment. Whereas some close relationships between Macaronesian and eastern African-southern Arabian taxa have been demonstrated through molecular phylogenetic studies, such as the cases of Aeonium Webb \& Berthel. (Mes and Hart 1996), Euphorbia (Molero et al. 2002; Bruyns et al. 2006), and Solanum (Bohs and Olmstead 2001), others have been rejected, such as Adenocarpus DC. (Percy and Cronk 2002), Plocama (Andersson and Rova 1999), and Prenanthes (Kim et al. 1996), among others (reviewed by Andrus et al. [2004]).

Interisland colonization and diversification in Macaronesia. A point of interest for studies of island biogeography is how species diversify within an insular environment. As explained above, H. monogynum is endemic to Lanzarote, and $H$. alucense is endemic to La Gomera; thus, the most parsimonious hypothesis is that a common ancestor of the two first reached Lanzarote, which is closer to the African coast, and later colonized La Gomera. These two species then evolved independently because of their isolation. Both H. monogynum and $H$. alucense grow on the lowland scrub of their respective islands. Similar patterns of allopatric speciation via interisland colonization across similar ecological zones have been reported for several groups: Lotus (Allan et al. 2004), Pericallis (Panero et al. 1999), Sideritis (Barber et al. 2002, 2007), Sonchus and Gonospermum (Francisco-Ortega et al. 2001), and Bystropogon (Trusty et al. 2005), among others. However, in all these genera, radiation into different ecological zones, allowing for differentiation within a single island, has also been a significant speciation mechanism in these insular environments. In the case of the four endemic Madeiran Helichrysum, which have a single origin, speciation events should be explained by diversification within a single island, which could have been favored by radiation into different, isolated geographic zones within the island rather than by ecological shifts, because the four species occupy similar ecological zones, mainly sea cliffs. However, at present the only species that is quite isolated is $H$. monizii, for which a unique and very small population is known in the south of Madeira. The other three species do overlap in distribution area in some localities. In particular, H. melaleucum is widely distributed, found from sea cliffs to the higher parts of the Madeira, Porto Santo, and Deserta islands (R. Jardim, Madeira Botanical Garden, Funchal, Madeira, Portugal, personal communication).

The origin and expansion of the Mediterranean-Asiatic group. All analyses showed that the Mediterranean-Asiatic Helichrysum is a strongly supported monophyletic group, and the ITS-ETS combined data showed $H$. gossypinum as its sister taxon with $87 \%$ BS value. It seems likely that an ancestor of the whole Mediterranean-Asiatic group reached the Mediterranean basin, where the group expanded and diversified, occupying the whole basin. Species of sect. Stoechadina, with a predominantly western-central Mediterranean distribution, share numerous 
morphological characters with the Macaronesian species, which are sister to the Mediterranean-Asiatic group.

Our results suggest that the expansion through the Mediterranean was followed by colonization of the western and central Asiatic regions, likely related to the reduction in woodiness mentioned above, which may have permitted an adaptation to the high-mountain climate of these areas. Speciation appears to have been recent in the western and central Asiatic regions, evidenced by the scarce morphological and molecular divergence of the group, and it was probably affected by numerous hybridization events, as hybridization is still common within many of these species (M. Galbany-Casals and L. Sáez, personal observation). Moreover, the low levels of support for the internal nodes of a tree have sometimes been interpreted as a sign of reticulate evolution within a group of species (McDade 1992; Wendel and Doyle 1998; Font et al. 2002; Andreasen and Baldwin 2003; Fuertes Aguilar and Nieto Feliner 2003), because concerted evolution of the sequences in a hybrid results in their homogenization and therefore the loss of informative characters (Suárez-Santiago et al. 2007).

Helichrysum lacteum, which grows in the mountains of Morocco and Algeria, is a hemicryptophyte and appears as the basal species in the Asiatic clade ( $\mathrm{BS}=95 \%, \mathrm{PP}=1$; fig. 5). This finding indicates a secondary colonization of the southwestern Mediterranean area from western Asia or the eastern Mediterranean region. The ancestor of $H$. lacteum could have reached the North African mountains during times of land connections in the Mediterranean, either during the Messinian crisis (Bocquet et al. 1978) or during Pleistocene glacial phases, when the sea level was also low (Quézel 1981), and then become isolated in several mountain areas. However, a long-distance dispersal event cannot be ruled out as a possible explanation for the presence of H. lacteum in the North African mountains. Further dispersion-vicariance and time estimation analyses would be useful to confirm one of these hypotheses.

\section{Acknowledgments}

We thank the curators of all herbaria that provided material (BM, E, HUB, IRAN, LE, MA, RNG, TFC, W), as well as Kew Gardens and Jardí Botànic Mar i Murtra Blanes. Also special thanks are due to S. Arrabal, R. J. Bayer, J. M. Blanco, J. Burrows, T. Garnatje, M. Koekemoer, R. Jardim, J. M. Lanau, A. Lluent, J. M. Ninot, A. Pérez, A. Romo, C. Roquet, and J. Vallès for helping with field collections and/ or providing material; to R. Jardim, who provided interesting comments on the ecology and distribution of the Madeiran species; to C. Roquet, who provided technical assistance for the analyses; to J. Vallès, who transcribed Russian herbarium labels; to J. Ready and J. Burrows, who helped with identifications; to S. Pyke, who improved the English; and to A. Santos-Guerra, who kindly provided valuable comments on the manuscript. This work has been partly financed by the Spanish government (projects REN2002-04634-C05-01, CGL2004-04563-C02-01/BOS, and CGL2006-01765/BOS) and the Catalan government (Formació d'Investigadors [FI] to M. Galbany-Casals, "Ajuts a grups consolidats" 2005/ SGR/00344).

\section{Literature Cited}

Akaike H 1973 Information theory and an extension of the maximum likelihood principle. Pages 267-281 in BN Petrov, F Csáki, eds. Second international symposium on information theory. Akadémiai Kiadó, Budapest.

Allan GJ, J Francisco-Ortega, A Santos-Guerra, E Boerner, EA Zimmer 2004 Molecular phylogenetic evidence for the geographic origin and classification of Canary Island Lotus (Fabaceae: Loteae). Mol Phylogenet Evol 32:123-138.

Anderberg AA 1991 Taxonomy and phylogeny of the tribe Gnaphalieae (Asteraceae). Opera Bot 104:1-195.

Andersson L, JHE Rova 1999 The rps16 intron and the phylogeny of the Rubioideae (Rubiaceae). Plant Syst Evol 214:161-186.

Andreasen K, B Baldwin 2003 Nuclear ribosomal DNA sequence polymorphism and hybridization in checker mallows (Sidalcea, Malvaceae). Mol Phylogenet Evol 29:563-581.

Andrus N, J Trusty, A Santos-Guerra, RK Jansen, J Francisco-Ortega 2004 Using molecular phylogenies to test phytogeographical links between east/south Africa-southern Arabia and the Macaronesian islands: a review, and the case of Vierea and Pulicaria sect. Vieraeopsis (Asteraceae). Taxon 53:333-346.

Axelrod DI 1975 Evolution and biogeography of Madrean-Tethyan sclerophyll vegetation. Ann Mo Bot Gard 62:280-334.

Baldwin BG, S Markos 1998 Phylogenetic utility of the external transcribed spacer (ETS) of 18S-26S rDNA: congruence of ETS and ITS trees of Calycadenia (Compositae). Mol Phylogenet Evol 10:449-463.

Barber JC, CC Finch, J Francisco-Ortega, A Santos-Guerra, RK Jansen 2007 Hybridization in Macaronesian Sideritis (Lamiaceae): evidence from incongruence of multiple independent nuclear and chloroplast sequence datasets. Taxon 56:74-88.

Barber JC, J Francisco-Ortega, A Santos-Guerra, KG Turner, RK
Jansen 2002 Origin of Macaronesian Sideritis L. (Lamioideae: Lamiaceae) inferred from nuclear and chloroplast sequence datasets. Mol Phylogenet Evol 23:293-306.

Bayer RJ, I Breitwieser, J Ward, CF Puttock 2007 Tribe Gnaphalieae (Cass.) Lecoq \& Juillet (1831). Pages 246-284 in JW Kadereit, C Jeffrey, eds. The families and genera of vascular plants. Vol VIII. Asterales. Springer, Berlin.

Bayer RJ, DG Greber, NH Bagnall 2002 Phylogeny of Australian Gnaphalieae (Asteraceae) based on chloroplast and nuclear sequences, the $t r n \mathrm{~L}$ intron, $t r n \mathrm{~L} / \mathrm{F}$ intergenic spacer, mat $\mathrm{K}$, and ETS. Syst Bot 27:801-814.

Bayer RJ, CF Puttock, SA Kelchner 2000 Phylogeny of South African Gnaphalieae (Asteraceae) based on two noncoding chloroplast sequences. Am J Bot 87:259-272.

Beentje HJ 2002 Helichrysum. Pages 403-452 in HJ Beentje, ed. Flora of tropical East Africa. Pt 2. Balkema, Rotterdam.

Bena G, MF Jubier, I Olivieri, B Lejeune 1998 Ribosomal external and internal transcribed spacers: combined used in the phylogenetic analysis of Medicago (Leguminosae). J Mol Evol 46:299-306.

Bocquet G, B Widler, H Kiefer 1978 The Messinian model: a new outlook for the floristics and systematics of the Mediterranean area. Candollea 33:269-287.

Bohs L, RG Olmstead 2001 A reassessment of Normania and Triguera (Solanaceae). Plant Syst Evol 228:33-48.

Bramwell D 1976 The endemic flora of the Canary Islands: distribution, relationships and phytogeography. Pages 207-240 in G Kunkel, ed. Biogeography and ecology in the Canary Islands. Junk, The Hague.

1985 Contribución a la biogeografía de las Islas Canarias. Bot Macaron 14:3-34. 
Bremer B 1996 Phylogenetic studies within Rubiaceae and relationships to other families based on molecular data. Opera Bot Belg 7: 33-50.

Bruyns PV, RJ Mapaya, T Hedderson 2006 A new subgeneric classification for Euphorbia (Euphorbiaceae) in southern Africa based on ITS and $p s b \mathrm{~A}-\mathrm{trn} \mathrm{H}$ sequence data. Taxon 55:397-420.

Carine MA, SJ Russell, A Santos-Guerra, J Francisco-Ortega 2004 Relationships of the Macaronesian and Mediterranean floras: molecular evidence for multiple colonizations into Macaronesia and backcolonization of the continent in Convolvulus (Convolvulaceae). Am J Bot 91:1070-1085.

Carracedo JC, S Day, H Guillou, E Rodríguez Badiola, JA Canas, FJ Pérez Torrado 1998 Hotspot volcanism close to a passive continental margin: the Canary Islands. Geol Mag 135:591-604.

Clapham AR 1976 Helichrysum. Pages 128-131 in TG Tutin, VH Heywood, NA Burges, DM Moore, DH Valentine, SM Walters, DA Webb, eds. Flora Europaea. Vol 4. Cambridge University Press, London.

Clevinger JA, JL Panero 2000 Phylogenetic analysis of Silphium and subtribe Engelmanniinae (Asteraceae: Heliantheae) based on ITS and ETS sequence data. Am J Bot 87:565-572.

Cline J, JC Braman, HH Hogrefe 1996 PCR fidelity of pfu DNA polymerase and other thermostable DNA polymerases. Nucleic Acids Res 24:3546-3551.

Comes HP, RJ Abbott 2001 Molecular phylogeography, reticulation, and lineage sorting in Mediterranean Senecio sect. Senecio (Asteraceae). Evolution 55:1943-1962.

Cuénoud P, MADP Martínez, P-A Loizeau, R Spichiger, S Andrews, J-F Manen 2000 Molecular phylogeny and biogeography of the genus Ilex L. (Aquifoliaceae). Ann Bot 85:111-122.

Cullings KW 1992 Design and testing of a plant-specific PCR primer from ecological and evolutionary studies. Mol Ecol 1:233-240.

de Candolle AP 1838 Prodromus systematis naturalis regni vegetabilis. Vol 6. Treuttel \& Würtz, Paris.

Doyle JJ, JL Doyle 1987 A rapid DNA isolation procedure for small quantities of fresh leaf tissue. Phytochem Bull 19:11-15.

Farris JS, M Källersjö, AG Kluge, C Bult 1994 Testing significance of incongruence. Cladistics 10:315-319.

Felsenstein J 1985 Confidence limits on phylogenies: an approach using the bootstrap. Evolution 39:783-791.

Font M, T Garnatje, N Garcia-Jacas, A Susanna 2002 Delineation and phylogeny of Centaurea sect. Acrocentron based on DNA sequences: a restoration of the genus Crocodylium and indirect evidence of introgression. Plant Syst Evol 234:15-26.

Francisco-Ortega J, JC Barber, A Santos-Guerra, R Febles-Hernández, RK Jansen 2001 Origin and evolution of the endemic genera of Gonosperminae (Asteraceae: Anthemideae) from the Canary Islands: evidence from nucleotide sequences of the internal transcribed spacers of the nuclear ribosomal DNA. Am J Bot 88:161-169.

Francisco-Ortega J, J Fuertes-Aguilar, S-C Kim, A Santos-Guerra, DJ Crawford, RK Jansen 2002 Phylogeny of the Macaronesian endemic Crambe section Dendrocrambe (Brassicaceae) based on internal transcribed spacer sequences of nuclear ribosomal DNA. Am J Bot 89:1984-1990.

Francisco-Ortega J, LR Goertzen, A Santos-Guerra, A Benabid, RK Jansen 1999 Molecular systematics of the Asteriscus alliance (Asteraceae: Inuleae). I. Evidence from the internal transcribed spacers of nuclear ribosomal DNA. Syst Bot 24:249-266.

Francisco-Ortega J, A Santos-Guerra, A Hines, RK Jansen 1997 Molecular evidence for a Mediterranean origin of the Macaronesian endemic genus Argyranthemum (Asteraceae). Am J Bot 84:15951613.

Fuertes Aguilar J, G Nieto Feliner 2003 Additive polymorphisms and reticulation in an ITS phylogeny of thrifts (Plumbaginaceae). Mol Phylogenet Evol 28:430-447.
Fuertes-Aguilar J, MF Ray, J Francisco-Ortega, A Santos-Guerra, RK Jansen 2002 Molecular evidence from chloroplast and nuclear markers for multiple colonizations of Lavatera (Malvaceae) in the Canary Islands. Syst Bot 27:74-83.

Fuertes Aguilar J, JA Rosselló, G Nieto Feliner 1999 Molecular evidence for the compilospecies model of reticulate evolution in Armeria (Plumbaginaceae). Syst Biol 48:735-754.

Galbany-Casals M, N Garcia-Jacas, A Susanna, L Sáez, C Benedí 2004a Phylogenetic relationships in the Mediterranean Helichrysum (Asteraceae, Gnaphalieae) based on nuclear rDNA ITS sequence data. Aust Syst Bot 17:241-253.

Galbany-Casals M, L Sáez, C Benedí 2004b Notes taxonòmiques en plantes mediterrànies. Butl Inst Catalana Hist Nat 71:133-134.

2004c Taxonomy of Castroviejoa, a new genus of Gnaphalieae (Asteraceae), endemic to the Mediterranean islands Corsica and Sardinia. Aust Syst Bot 17:581-591.

2006 A taxonomic revision of Helichrysum Mill. sect. Stoechadina (DC.) Gren. \& Godr. (Asteraceae, Gnaphalieae). Can J Bot 84:1203-1232.

Goodson BE, A Santos-Guerra, RK Jansen 2006 Molecular systematics of Descurainia (Brassicaceae) in the Canary Islands: biogeographic and taxonomic implications. Taxon 55:671-682.

Helfgott DM, J Francisco-Ortega, A Santos-Guerra, RK Jansen, BB Simpson 2000 Biogeography and breeding system evolution of the woody Bencomia alliance (Rosaceae) in Macaronesia based on ITS sequence data. Syst Bot 25:82-97.

Hess JJ, W Kadereit, P Vargas 2000 The colonization history of Olea europaea L. in Macaronesia based on internal transcribed spacer 1 (ITS-1) sequences, randomly amplified polymorphic DNAs (RAPD), and intersequence simple repeats (ISSR). Mol Ecol 9:857-868.

Hilliard OM 1983 Helichrysum Mill. Pages 61-310 in OA Leistner, ed. Flora of southern Africa. Vol 33, pt 7, fasc 2. Botanical Research Institute, Pretoria.

Hilliard OM, BL Burtt 1981 Some generic concepts in CompositaeGnaphaliinae. Bot J Linn Soc 82:181-232.

Huelsenbeck P, F Ronquist 2001 MRBAYES: Bayesian inference of phylogenetic trees. Bioinformatics 17:754-755.

Humbert H 1962 Helichrysum. Pages 389-565 in Flore de Madagascar et des Comores. Vol 2. Múseum National d'Histoire Naturelle, Paris.

Illa E, E Carrillo, JM Ninot 2006 Patterns of plant traits in Pyrenean alpine vegetation. Flora 201:528-546.

Kim S-C, DJ Crawford, J Francisco-Ortega, A Santos-Guerra 1996 A common origin for woody Sonchus and five related genera in the Macaronesian Islands: molecular evidence for extensive radiation. Proc Natl Acad Sci USA 93:7743-7748.

Körner C 1999 Alpine plant life: functional plant ecology of high mountain ecosystems. Springer, Berlin.

Lee C, S-C Kim, K Lundy, A Santos-Guerra 2005 Chloroplast DNA phylogeny of the woody Sonchus alliance (Asteraceae: Sonchinae) in the Macaronesian Islands. Am J Bot 92:2072-2085.

Lidén M, T Fukuhara, J Rylander, B Oxelman 1997 Phylogeny and classification of Fumariaceae, with emphasis on Dicentra s. 1. based on the plastid gene rps16 intron. Plant Syst Evol 206:411-420.

Linder CR, LR Goertzen, BV Heuvel, J Francisco-Ortega, RK Jansen 2000 The complete external transcribed spacer of 18S-26S rDNA: amplification and phylogenetic utility at low taxonomic levels in Asteraceae and closely allied families. Mol Phylogenet Evol 14:285-303.

Maddison DR 1991 The discovery and importance of multiple islands of most-parsimonious trees. Syst Zool 40:315-328.

Markos S, BG Baldwin 2001 Higher-level relationships and major lineages of Lessingia (Compositae, Astereae) based on nuclear rDNA internal and external transcribed spacers (ITS and ETS) sequences. Syst Bot 26:168-183. 
Martín-Bravo S, H Meimberg, M Luceño, W Märkl, V Valcárcel, C Bräuchler, P Vargas, G Heubl 2007 Molecular systematics and biogeography of Resedaceae based on ITS and $t r n \mathrm{~L}-\mathrm{F}$ sequences. Mol Phylogenet Evol 44:1105-1120.

McDade LA 1992 Hybrids and phylogenetic systematics II. The impact of hybrids on cladistic analysis. Evolution 46:1329-1346.

Mes THM, H Hart 1996 The evolution of the growth-forms in the Macaronesian genus Aeonium (Crassulaceae) inferred from chloroplast DNA RFLPs and morphology. Mol Ecol 5:351-363.

Molero J, T Garnatje, A Rovira, N Garcia-Jacas, A Susanna 2002 Karyological evolution and molecular phylogeny in Macaronesian dendroid spurges (Euphorbia subsect. Pachycladae). Plant Syst Evol 231:109-132.

Nieto Feliner G, B Gutiérrez Larena, J Fuertes Aguilar 2004 Finescale geographical structure, intra-individual polymorphism and recombination in nuclear ribosomal internal transcribed spacers in Armeria (Plumbaginaceae). Ann Bot 93:189-200.

Nordenstam B 2003 Further contributions to the genus Syncarpha (Compositae-Gnaphalieae). Compositae Newlett 39:52-57.

Nylander JAA 2004 MrModeltest, version 2. Program distributed by the author. Evolutionary Biology Centre, Uppsala University, Uppsala.

Okuyama Y, N Fujii, M Wakabayashi, A Kawakita, M Ito, M Watanabe, N Murakami, M Kato 2005 Nonuniform concerted evolution and chloroplast capture: heterogeneity of observed introgression patterns in three molecular data partition phylogenies of Asian Mitella (Saxifragaceae). Mol Biol Evol 22:285-296.

Panero JL, J Francisco-Ortega, RK Jansen, A Santos-Guerra 1999 Molecular evidence for multiple origins of woodiness and a New World biogeographic connection of the Macaronesian island endemic Pericallis (Asteraceae: Senecioneae). Proc Natl Acad Sci USA 96:13886-13891.

Park SJ, EJ Korompai, J Francisco-Ortega, A Santos-Guerra, RK Jansen 2001 Phylogenetic relationships of Tolpis based on $n d b \mathrm{~F}$ sequence data. Plant Syst Evol 226:23-33.

Percy DM, QCB Cronk 2002 Different fates of island brooms: contrasting evolution in Adenocarpus, Genista, and Teline (Genisteae, Fabaceae) in the Canary Islands and Madeira. Am J Bot 89: 854-864.

Popp M, B Oxelman 2001 Inferring the history of the polyploid Silene aegaea (Caryophyllaceae) using plastic and homoeologous nuclear DNA sequences. Mol Phylogenet Evol 20:474-481.

Quézel P 1978 Analysis of the flora of Mediterranean and Saharan Africa. Ann Mo Bot Gard 65:479-534.

1981 Les hautes montagnes du Maghreb et du Proche-Orient: essai de mise en parallèle des caractères phytogéographiques. An Jard Bot Madr 37:353-372.

Rodríguez F, JR Oliver, A Marín, JR Medina 1990 The general stochastic model of nucleotide substitution. J Theor Biol 142: 485-501.

Ronquist F, JP Huelsenbeck 2003 MRBAYES 3: Bayesian phylogenetic inference under mixed models. Bioinformatics 19:1572-1574.
Suárez-Santiago VN, MJ Salinas, N Garcia-Jacas, PS Soltis, DE Soltis, G Blanca 2007 Evolution by reticulation of the Acrolophus subgroup (Centaurea L., Compositae) in the Occidental Mediterranean: origin and diversification of the section Willkommia Blanca. Mol Phylogenet Evol 43:156-172.

Sun Y, DZ Skinner, GH Liang, SH Hulbert 1994 Phylogenetic analysis of Sorghum and related taxa using internal transcribed spacers of nuclear ribosomal DNA. Theor Appl Genet 89:26-32.

Sunding P 1979 Origins of the Macaronesian flora. Pages 13-40 in D Bramwell, ed. Plants and islands. Academic Press, London.

Swofford DL 2002 PAUP*: phylogenetic analysis using parsimony ("and other methods), version 4.0b10. Sinauer, Sunderland, MA.

Swofford DL, GJ Olsen 1990 Phylogeny reconstruction. Pages 411-501 in D Hillis, C Moritz, eds. Molecular systematics. Sinauer, Sunderland, MA.

Tadesse M, T Reilly 1995 A contribution to studies on Helichrysum (Compositae-Gnaphalieae): a revision of the species of north-east tropical Africa. Pages 379-450 in DJN Hind, C Jeffrey, GV Pope, eds. Advances in Compositae systematics. Royal Botanic Gardens, Kew.

Thiv M, L Struwe, JW Kadereit 1999 The phylogenetic relationships and evolution of the Canarian laurel forest endemic Ixanthus viscosus (Aiton) Griseb. (Gentianaceae): evidence from matK and ITS sequences, and floral morphology and anatomy. Plant Syst Evol 218:299-317.

Trusty JL, RG Olmstead, A Santos-Guerra, S Sá-Fontinha, J FranciscoOrtega 2005 Molecular phylogenetics of the Macaronesianendemic genus Bystropogon (Lamiaceae): palaeo-islands, ecological shifts and interisland colonizations. Mol Ecol 14:1177-1189.

Urbatsch LE, RP Roberts, V Karaman 2003 Phylogenetic evaluation of Xylothamia, Gundlachia, and related genera (Asteraceae, Astereae) based on ETS and ITS nrDNA sequence data. Am J Bot 90:634649.

Vargas P, HA McAllister, C Morton, SL Jury, MJ Wilkinson 1999a Polyploid speciation in Hedera (Araliaceae): phylogenetic and biogeographic insights based on chromosome counts and ITS sequences. Plant Syst Evol 219:165-179.

Vargas P, CM Morton, SL Jury $1999 b$ Biogeographic patterns in Mediterranean and Macaronesian species of Saxifraga (Saxifragaceae) inferred from phylogenetic analyses of ITS sequences. Am J Bot 86:724-734.

Vilatersana R, AK Brysting, C Brochmann 2007 Molecular evidence for hybrid origins of the invasive polyploids Carthamus creticus and C. turkestanicus (Cardueae, Asteraceae). Mol Phylogenet Evol 44: 610-621.

Wendel JF, JJ Doyle 1998 Phylogenetic incongruence: window into genome story and molecular evolution. Pages 265-296 in DE Soltis, PS Soltis, JJ Doyle, eds. Molecular systematics of plants II: DNA sequencing. Kluwer, Boston.

Yang Z 1996 Among-site rate variation and its impact on phylogenetic analyses. Trends Ecol Evol 11:367-372. 